\title{
USO DE ANTICORPO POLICLONAL ESPECÍFICO PARA NUCLEOPROTEÍNA RECOMBINANTE DO VÍRUS A BRONQUITE INFECCIOSA (VBI) NA TÉCNICA DE IMUNO-HISTOQUÍMICA (IHC) PARA DETECÇÃO DE DIFERENTES ESTIRPES DO VBI
}

\author{
(USE OF SPECIFIC POLYCLONAL ANTIBODY TO RECOMBINANT NUCLEOPROTEIN OF
} INFECTIOUS BRONCHITIS VIRUS IN THE IMMUNOHISTOCHEMISTRY (IHC) FOR THE DETECTION OF DIFFERENT IBV STRAINS)

\section{F. S. FERNANDO ${ }^{1}$, M. M. BORZI ${ }^{1}$, A. M. GIBERTONI ${ }^{1}$, M. B. BANDARRA ${ }^{1}$, M.F.S. MONTASSIER $^{1}$, H. J. MONTASSIER ${ }^{2 *}$}

Infecção por IBV é uma importante doença que ameaça a indústria de ave em todo o mundo e pode estar envolvida com doenças respiratórias, nefrite e produção de ovos. O diagnóstico convencional do IBV baseia-se no isolamento do vírus em ovos embrionados, seguido de identificação molecular ou imunológica dos isolados, tornando estes procedimentos fastidiosos e demorados. Assim, foi proposto o desenvolvimento do método de IHC para detectar o antígeno de IBV em amostras de tecido, utilizando um soro hiperimune de cabra contra a nucleoproteína recombinante (RN), para a detecção de três diferentes cepas virais de IBV. Uma cabra foi imunizada com proteína $\mathrm{N}$ recombinante expressa em Escherichia coli, e depois de cinco imunizações, o soro anti-IBV foi obtido e analisado por ELISA para titulação de anticorpos específicos anti-IBV e Western blot para usar como anticorpo primário, juntamente com o complexo secundário contendo um polímero ligado a peroxidase usando a técnica IHC para detectar antígenos de IBV nas amostras de tecido. Amostras de tecido traqueal e renal foram coletadas de três grupos de galinhas SPF alojadas em isoladores de pressão positiva; experimentalmente infectadas com as cepas Massachusetts, IBVPR-05 ou IBVPR12, respectivamente, e o grupo de controle que permaneceu não-infectado. A presença do antígeno de IBV foi detectada no citoplasma das células epiteliais de amostras de traqueia em todos os grupos desafiados, enquanto que as células dos túbulos renais foram marcadas positivamente pela técnica de IHQ em todas as amostras dos grupos desafiados com cepas IBVPR-05-12 e IBVPR, mas não em amostras de rim de aves desafiadas com a cepa Massachusetts. No grupo de controle não foram detectados por IHQ antígenos de IBV em amostras de tecido. Concluindo, a técnica de IHC com o anticorpo policlonal de cabra contra a proteína RN de IBV, foi capaz de detectar especificamente antígenos de IBV em amostras de tecidos de galinhas infectadas com uma estirpe variante e pode ser uma alternativa vantajosa para diagnosticar a infecção direta por IBV, ou mesmo para o método de isolamento de vírus.

\footnotetext{
${ }^{1}$ Programa de pós-graduação, Faculdade de Ciências Agrárias e Veterinárias - UNESP Jaboticabal, SP, Brasil.

2* Departamento de Patologia Veterinária, Faculdade de Ciências Agrárias e Veterinárias -UNESP- Jaboticabal.

E-mail: heliojm@fcav.unesp.br
} 